\title{
Foreign powers competition in the mining sector of Mongolia
}

\author{
Vladimir Rodionov ${ }^{1 a}$, Innokentii Aktamov ${ }^{1}$, Damdin Badaraev², Timur Badmatsyrenov ${ }^{1}$, Aleksey Kombaev ${ }^{1}$, Irina \\ Dorzhieva $^{1}$ \\ ${ }^{1}$ Buryat State University 670000, Smolina Str. 24a, Ulan-Ude, Russia \\ ${ }^{2}$ Institute for Mongolian, Buddhist and Tibetan Studies RAS (SB), 670047, Sakhiyanova Str. 6, Ulan-Ude, Russia
}

\begin{abstract}
The paper is about the issue of Mongolia cooperation with foreign companies playing an important role in its foreign policy strategy and national security. At the beginning of the 1990s, having proclaimed a "multipillar" policy strategy in relations with the world, Ulaanbaatar tends to follow it in the economic cooperation not willing to give any preference to any country. It creates a situation of competition between foreign companies backed by their states, especially such great powers as Russia, China, the USA. The most tense moment in the struggle for the influence in Mongolia is the rivalry between the different discourses, pretending the exclusive right to nominate the most effective model of cooperation between Mongolia and foreign states in the ore-mining industry. Among the most well-defined discourses, there are three of them. China prefers to define the discourse of "economic feasibility". Western states, as a rule, tend to rely on the discourse of "values community", which includes such concepts as "democracy", "environmentally friendly", "transparency" Russia often uses the "geopolitical" discourse. In spite of the attractiveness and relative effectiveness of the discourse selected by Russia, there are certain limits to its use.
\end{abstract}

\section{Introduction}

A few years ago modern economy of Mongolia was going through a boom, linked with the development of the mining industry. Vast resources of coal, copper, gold, uranium and other minerals are considered by the government as a major source of economic wealth of Mongolia. According to the Mongolia Government estimates, only gold and copper entrails of Oyu Tolgoi can bring the country incomings in the amount equal to $30 \%$ of GDP. The potential incomings from Tavan Tolgoi coal deposit will form the basis for the social benefits from the "Human Development Foundation" [1]. According to the World Bank estimates, GDP will increase to $\$ 24$ billion the next 10 years due to big incomings from exploration of Tavan Tolgoi and Oyu Tolgoi. During last year, GDP was not more than \$15 billion [2]. One of the key conditions of Mongolia's economic development is the involvement of foreign companies in the development of large-scale mining. Moreover, the issue of cooperation with foreign companies plays an important role in Mongolian foreign policy strategy and national security.

Table 1. Vast mineral resources of Mongolia.

\begin{tabular}{|c|c|}
\hline Mining products & Proved reserves \\
\hline Coal & 162 billions of tons \\
\hline
\end{tabular}

a Corresponding author: vladimir_198025@mail.ru

\begin{tabular}{|c|c|}
\hline Copper & 36 millions of tons \\
\hline Uranium & 75 thousands of tons \\
\hline Iron ore & 11 billions of tons \\
\hline Zinc & 1 millions of tons \\
\hline
\end{tabular}

At the beginning of the $1990 \mathrm{~s}$, having proclaimed a "multipillar" (olon tulguurt) policy strategy in relations with the world, Ulaanbaatar tends to follow it in the economic cooperation, not willing to give any preference to any country. It creates a situation of competition between foreign companies. This competition is marked as the geopolitical rivalry of Great Powers. Mongolian officials comment on the situation emphasizing the connection between the geographic isolation of the country between Russia and China, and the problem of choosing a foreign investor for large mineral deposits. Most large foreign companies, interested in the mining sector of Mongolia, are supported by their Government (for example, Japanese companies «Mitsui» and «Marubeni», American «Peabody Energy») or they are state companies themselves (Chinese «Shenhua Energy» and «China National Nuclear Cooperation Overseas Uranium», Russian JSC "RZD" and JSC "Atomredmetzoloto," South Korean «Korean resources»).

Table 2. Leading foreign companies with interests in mining sector of Mongolia. 


\begin{tabular}{|l|c|l|}
\hline \multicolumn{1}{|c|}{ Company } & Country & \multicolumn{1}{c|}{$\begin{array}{c}\text { Area of } \\
\text { interests }\end{array}$} \\
\hline Shenhua Energy & China & Coal \\
\hline Peabody Energy & USA & Coal \\
\hline Areva & France & Uranium \\
\hline Rio Tinto & Australia & Copper, gold \\
\hline Marubeni & Japan & Coal, Uranium \\
\hline Russian Railways & Russia & Coal \\
\hline Centerra Gold & Canada & Gold \\
\hline
\end{tabular}

It should be emphasized that the current conditions of competition for the influence in the region are unique in terms of the historical experience of the XX century. The beginning of the last century was marked by the secession of Outer Mongolia from the Qing Empire with the Russian Empire support (including the military support). Further developments related to the attainment Mongolia's independence and national sovereignty were also associated with the use of force (whether its straight use or threat of use). This was the case with the struggle against the Chinese occupation and troops of Baron Ungern in the battles against Japan on the river Khalkhin Gol, confrontation in the 1960-80s with the PRC. Only the withdrawal of Soviet troops from Mongolia in the late 1980s led to the situation when the country was no longer treated as the arena of direct military confrontation between the great powers. These changes have become a precondition for the radically new international political situation around Mongolia, characterized by non-military rivalry between the great powers.

\section{Materials and methods}

This situation can be described with the help of distinction, suggested by a professor of Harvard University, Joseph Nye Jr., between "hard power" and "soft power". Nye understands "soft power" as "the ability of the state (union coalition) to achieve the desired outcomes in international affairs through persuasion (attraction) ... using ideology, science and culture as an effective instrument of their own political influence on other countries". In return, the "hard" power includes such methods of foreign policy as military, political, and economic impact [3]. Manifestations of "hard power" - military and political actions and economic sanctions - are effective in the open confrontation in the region. In case of Mongolia, maintaining friendly relations with all major powers, these factors are ineffective. The factors of "soft power" are more effective in this situation, they are manifested in the formation of a loyal political elite focused on the appropriate values of the general public in collaboration with NGOs (non-governmental organizations), etc. Through these factors it is possible to set up the profitable political agenda, getting access to its management. The example of such control can take part in the decision-making - which company / country meets their requirements to modern technology, activity transparency, sustainability, etc.

\section{Results and discussion}

One of the most distinct segments in the struggle, where the methods of "soft power" are widely used, is the oremining sector of Mongolia. The tensest moment in the struggle for the influence in Mongolia is the rivalry between the different discourses, pretending to the exclusive right to nominate the most effective model of cooperation of Mongolia with foreign states in the oremining industry. Among the most well-defined discourses there are three of them.

First. China today is the most important economic partner of Mongolia, both in trade and in investments. However, due primarily to historical reasons, China is seen in Mongolia not only as a source of economic growth, but also as the most current external challenge to national security. Therefore, the Chinese side, unable to rely on its own positive image in Mongolia and to become a center of cultural and ideological attraction, prefers to define the discourse of "economic feasibility". This discourse is based on the priority of purely economic interests when choosing a foreign partner.

Compilers of this discourse are the Chinese government and the business community, as well as several private Mongolian companies, including international economic organizations. For example, the Mongolian mining company «Energy Resources» is actively lobbying for a project to build a railway from Tavan Tolgoi to the Chinese border. The World Bank strongly recommended the Mongolian government to build the railroad directly to China. The Executive Director of Coal Association in Mongolia, T. Naran, spoke for the Chinese port of Tianjin in the transportation of Mongolian coal to markets in the Far East, saying that "China, not Russia, is the best partner for us in the export of coal abroad" [4].

In the framework of this discourse, the high probability of Mongolia to become raw materials appendage of China due to Beijing's chosen strategy is ignored. The essence of this strategy is the following. Chinese companies focus on buying large mineral deposits of foreign countries for further production and transportation in order to process them on Chinese territory. For example, this practice takes place in the relations with Kazakhstan. In August 2005, the Chinese state "National Oil Company" acquired the Canadian company "Petro Kazakhstan", which owns licenses to develop oil fields in Kazakhstan. In December 2006, another Chinese company «CITIC Group» bought the Canadian company's «Nations Energy» oil assets worth U.S. \$ 1.9 billion [5, 6]. Another example of this strategy is the direction of the Australian-Chinese foreign policy. The Australian company «Centrex Metals» has sold half of its shares of magnetite deposits for $\$ 180$ million to the third-sized Chinese steel company «Wuhan Iron and Steel». The company «Grange Resources» also relies on the Chinese business and intends to merge with the «Australian Bulk Mineral», which mostly belongs to Chinese steel producers. Chinese «Sinosteel» infiltrated into the iron-ore district of Western Australia, having invested \$ 1.4 billion into the company «Midwest»; 
«Sinosteel» has also participated (49.9\% of shares) in the Australian company «Murchison Metals» [7].

Thus, the preferred option for China is a direct access to raw assets (natural resources and infrastructure) through obtaining licenses for exploration and extraction of raw materials, participation in equity companies, etc. In case of Mongolia, this situation occurs in the oil, uranium, coal industries. The Chinese company «PetroChina» is engaged in oil production in the area of Tamtsag, «China National Nuclear Cooperation Overseas Uranium» owns the license to develop uranium deposits Gurvan Bulag. The whole production of these fields in the raw form is sent or will be sent to China.

In carrying out this policy, China relies on such competitive advantages as extensive financial resources and close proximity of their own markets to mineral resources. In particular, the access to large natural deposits of the country is often provided by Beijing through the provision of financial assistance, and offering larger sums to purchase the assets of Mongolian and foreign companies.

Second. Western companies as a rule, tend to rely on the discourse of "values community (solidarity)", which includes such concepts as "democracy", "environmentally friendly", "transparency". Almost all official meetings of Mongolian leaders with the representatives of the Western ruling circles take place with reference to the "common democratic values." The theme of "common democratic values" is consistently applied "in a single package" with the issues of trade and economic and investment cooperation between the countries. Thus, during the conversation between Ts. Elbegdorj and B. Obama (as a part of the Mongolian President official visit to the United States in June, 2011), both sides emphasized "the importance of democracy, human rights and freedom protection and development, that are the common interests of both countries ... as well as the importance of intensification of trade and economic cooperation" [8].

The participation of foreign companies in the mining sector in Mongolia is supposed to be a guarantee against corruption and backwardness. The letter, written by companies "Rio Tinto" and "Ivanhoe Mines", addressed the members of the Mongolian Parliament in July 2009 (before the decision on the issue of copper and gold deposit Oyu Tolgoi) is indicative in this respect. As an argument designed to persuade the Mongolian side in the necessity of "correct" choice, the following thesis is provided: "Mongolia is at crossroads. One path leads to the development and an open society ... the other - to closed economy, and direct dependence on neighboring states" [9]. During his visit to Mongolia, the U.S. Deputy, Secretary of Commerce, S. Kumar, said that "if the international tender for Tavan Tolgoi is honest, the US Company "Peabody Energy" would gain the victory [10]. Thus, the Mongolian side was given a hint to understand that any choice of the Mongols, when American interests would not be taken into account, would be "unfair." In mass media, transmitted to Mongolia, you can often hear such phrases like: "The number of large companies, such as Rio Tinto will give them (the Mongols) the possibility of implementing international standards and stop fraud," [11]. G. Ulziyburen, a Chairman of the Office of Oil, said that he is confident that "British Gas" and "Central Asia Petroleum Corporation" will use environmentally friendly techniques and technology that meets international standards [12]. However, experience of the previous years does not always confirm these conclusions. Western companies working on the territory of Mongolia have been seen more than ones in the corruption schemes.

One of the central theme of massive protests in Mongolia is the problem of threats to the environment; an environmental issue was actively introduced into the socio-political agenda. Moreover, environmental issues are in close connection with the question of the exploitation of natural resources, and even in a broader context - the problem of environmental issues is a part of democracy and civil society in Mongolia. The US «Asian Foundation», working in Mongolia, has announced the program of "engagement of the shareholders in the debates on environmental issues" as one of its priorities. Under this program, it intends to exercise the functions of an "independent mediator" between government, business and civil society organizations (NGOs) to address environmental issues in connection with the activities of mining companies. Through acquiring these political agendas, its initiators have access to its management. Management of the agenda in this case involves a decision on what kind of company / what country meets the environmental requirements, and which one does not. However, as practice shows, some Western companies have a direct bearing on the multiplication of environmental problems in Mongolia, such as soil erosion, pollution and disappearance of rivers, and they are not particularly different from the companies of "undemocratic" countries.

It is also worth noting that the most Western companies interested only in economic profit, consider the Chinese market as the only potential market for the mining industry output. For example, «Peabody Energy» has a joint venture with a Chinese company «Winsway Coking Coal» to extract Mongolian coal and its subsequent sale to China. The Canadian-Australian tandem "Ivanhoe Mines" and "Rio Tinto" product Oyu Tolgoi also intend to be implemented in the Chinese market. Another Canadian company «Western Prospector Group», which until recently owned the licenses to develop uranium deposits Gurvan Bulag, preferred to sell their shares to a Chinese company. A similar story happened when the oilfield Tamtsag US company «Soko International»a sold assets to the Chinese company «PetroChina». Therefore, most Western companies are the natural partners of China in its policy on the closure of the market for mineral resources in Mongolia itself.

Third. The Russian side that has neither economic resources comparable with China, nor the access to the management of "democratic agenda", as a rule, often uses the "geopolitical" discourse. It is based on the principle of priority strategic interests of Russia and Mongolia in the field of mining. The increased economic 
dependence of Mongolia on China generates in the Mongolian society the images of "China threat." In this case the northern neighbor seems to be a "natural counterbalance to Chinese onslaught." Largely through the prism of ideas about "China threat", the image of Russia as "the most reliable ally" is constructed. For several reasons Russia is seemed to be a possible counterweight to the complete economic dependence on China. In the Mongol strategy, the factor of "China threat" in favor of Russia and its Far Eastern territories also plays a significant role. Mongolia is therefore seen as a "natural buffer", moving away the Russian territory from China. Non-Chinese hegemony in the field of mineral resources in Mongolia is an important goal of Russian policy.

For these reasons, the Russian companies, in contrast to the Western ones, in its activities are guided not only with the principles of pure economic benefits, but also with the strategic interests of the Russian state, interested in the preservation of Mongolia outside the monopoly power of China. A striking illustration of this thesis is the words of the former head of the Russian Embassy in Mongolia, V. Samoylenko. He says: "The Russian side is interested in the development of Tavan Tolgoi not just to make money and make a profit ... this is a mechanism to obtain funds that will ensure the return of our investments in the construction of new railway and a deep modernization of the Ulaanbaatar Railway" [13]. In this sense, Russia's geopolitical interests coincide with the interests of national security of Mongolia. The decision of the Mongolian Parliament in 2010 for the construction of a broad-gauge railway from Tavan Tolgoi to the side of the Russian border for the purpose of further transportation of coal through the territory of Russia was largely dictated by the "geopolitical" discourse [14].

\section{Conclusion}

At the same time it is worthwhile noting that in spite of the attractiveness and relative effectiveness of the discourse selected by Russia, there are certain limits to its use. Ulaanbaatar cannot always sacrifice the economic benefits to the development of relations with China, as well as neglect relationships with Western companies. Hence, there is an objective for the Russian government and the local business to link their own strategic and economic interests with the interests of Mongolia in the field of national security.

\section{Acknowledgment}

The study was conducted within the framework of the project of the Ministry of Education and Science of the Russian Federation, project №3433.

\section{References}

1. Mongolia segodnya (03.04.2011)
2. Mongolian Statistical Yearbook (Ulaanbaatar: National Statistical Office of Mongolia, 2014)

3. J. Nye, Soft Power. The Means to Success in World Politics (2004)

4. Mongolia segodnya (17.01.2011)

5. China's CITIC Group acquires Kazakhstan oil assets for 1,91 bln US dollars", People's Daily (English edition) (01.01.2007)

6. "CNPC secures Petro Kazakhstan bid" (BBC News, 26.10.2005)

7. V.A. Arkhipov, AIAT, 2, 15-16 (2010)

8. Montsame, (17.06.2011)

9. Ulaanbaatar Post (08.11.2009)

10. Mongolia segodnya (30.10.2011)

11. E. Dykstra, Ulaanbaatar Post, (21.05.2011)

A. Burenjargal, Gazryn tosny salbaryn tuukhend shine khuudas neelee, (22.06.2015) http://www.mongolianeconomy.mn/mn/e/8221

12. V.V. Samoylenko, An interview with the head of Russian Embassy in Mongolia http://www.mongolia.mid.ru/int_15.html

13. P. Maškarinec, ES, 36, 186-191 (2014) 